\title{
Host specificity and aggregation for a widespread mistletoe in Campo Rupestre vegetation ${ }^{\text {is }}$
}

\author{
Tadeu J. Guerra ${ }^{\mathrm{a}, \mathrm{b}, *}$, Marco A. Pizo ${ }^{\mathrm{c}}$, Wesley R. Silva ${ }^{\mathrm{d}}$ \\ a Programa de Pós-Graduação em Ecologia, Instituto de Biologia, Universidade Estadual de Campinas, 13083970, Campinas, São Paulo, Brazil \\ b Departamento de Botânica, Instituto de Ciências Biológicas, Universidade Federal de Minas Gerais, 6627, 31270-901, Belo Horizonte, MG, Brazil

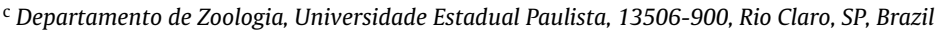 \\ d Departamento de Biologia Animal, Instituto de Biologia, Universidade Estadual de Campinas, C.P. 6109, 13083970, Campinas, São Paulo, Brazil
}

\section{A R T I C L E I N F O}

\section{Article history:}

Received 7 June 2016

Received in revised form

21 December 2016

Accepted 30 December 2016

Edited by P. Morellato

Available online 16 January 2017

\section{Keywords:}

Distribution

Loranthaceae

Myrtales

Psittacanthus robustus

Rocky outcrops

\begin{abstract}
A B S T R A C T
Assessment of host infection and distribution patterns are crucial to understand the underling mechanisms that shape parasitic plant spread in natural ecosystems. However, such data remain scarce for mistletoes inhabiting Brazilian campo rupestre vegetation, old-growth montane fire-prone grasslands. We evaluated the host range and distribution patterns of the mistletoe Psittacanthus robustus (Loranthaceae) at seven 1-ha plots located at in Serra do Cipó, southeastern Brazil. We investigate if the frequency of parasitism by $P$. robustus is directly related to the relative abundance of host tree species in the community, and how prevalence and intensity of infection vary among different host tree species. Average mistletoe density was 120 individuals ha ${ }^{-1}$, which parasitized eight host species, including trees and shrubs in five families. Four tree species, Vochysia thyrsoidea, Qualea cordata (Vochysiaceae), Trembleya laniflora and Miconia ferruginata (Melastomataceae), comprised 95\% of infected individuals. Twenty two percent of 1,108 trees sampled were parasitized by $P$. robustus, with host specificity within species in Myrtales Clade. Prevalence increased with host height for all tree species, with a highly aggregated distribution in few taller host trees within rocky outcrop patches in campo rupestre. The unveiling patterns of host infection and mistletoe distribution, support future studies addressing plant-plant, bird-plant and fire-plant interactions that might shape infection dynamics of this widespread mistletoe species in campo rupestre.
\end{abstract} (c) 2017 Elsevier GmbH. All rights reserved.

\section{Introduction}

Obligate parasitic flowering plants, popularly known as mistletoes, attach to the hosts' aerial shoots via a specialized root called haustorium (Calder and Bernardt, 1983). Most species are hemiparasites, obtaining water and mineral nutrients from the hosts' xylem, but photosynthesizing most of their own carbohydrates (Ehleringer et al., 1985). Host compatibility relates to physiological and morphological adaptations that allow seeds overcome hosts' chemical (Hoffmann et al., 1986) and mechanical (Medel, 2000) defensive traits to establish effective vascular connection (Yan, 1993). Mistletoe species varies in their host specificity, with some parasitizing only few host species within one genera or family, whereas oth-

\footnotetext{
is This article is part of a special issue entitled Plant life in campo rupestre: new lessons from an ancient biodiversity hotspot published at the journal FLORA 238C.

* Corresponding author at: Universidade Federal de Minas Gerais, Instituto de Ciências Biológicas, Departamento de Botânica, 6627, 31270-901, Belo Horizonte, MG, Brazil.

E-mail address: guerra.tj@gmail.com (T.J. Guerra).
}

ers are highly generalists infecting a wide range of hosts including native and exotic species (Norton and Carpenter, 1998).

Understanding patterns of distribution and host infection is the first step to formulate hypothesis regarding underling mechanisms that shape parasitic plant spread in natural ecosystems. Mistletoe distribution is influenced by the interactions with their host plants (Sargent, 1995; López de Buen and Ornelas, 2002), with their avian seed dispersers (Watson and Rawsthorne, 2013) and by the environmental conditions (Botto-Mahan et al., 2000; Hist et al., 2011). Consistent patterns of mistletoe distribution and host infection have been reported for distinct species across ecosystems worldwide. For instance, their distribution is usually highly clumped on hosts, often on those larger and taller (Aukema and Martinez del Rio, 2002a; Roxburgh and Nicolson, 2007). At the landscape scale, their distribution is usually aggregated in some vegetation patches (Aukema, 2004; Hist et al., 2011).

Mistletoes comprise important elements of the vegetation in Brazilian ecosystems (Arruda et al., 2012). However, their patterns of distribution and infection of hosts has been investigated for few species in Brazilian savannas (Arruda et al., 2006; Mourão et al., 2006; Fadini and Lima, 2012; Genini et al., 2012). The woody mistletoe Psittacanthus robustus Mart. is a geographically widespread 
species in savannas of Central and South-eastern Brazil (Rizzini, 1980). It is known to parasitize 12 host species of Vochysiaceae and two species of Melastomataceae throughout its geographic range (Monteiro et al., 1992; Teodoro et al., 2010; Scalon et al., 2013). Indeed, this species usually presents a clumped distribution on the vegetation and infects the uppermost portions of taller host trees (Teodoro et al., 2010), with the population dynamics directly affected by fire occurrence (Teodoro et al., 2013). This mistletoe is one of the most conspicuous parasitic plant in the landscapes encompassing Rupestrian Grasslands or campo rupestre ( $C R$ hereafter), the Brazilian old-growth montane fire-prone vegetation mosaics with remarkable plant diversity and endemism (Silveira et al., 2016). Indeed, this species seem to play a keystone role as resource for insect herbivores (Guerra et al., 2011) and nectarivorous birds (Guerra et al., 2014) in $C R$ vegetation. However, patterns of mistletoe distribution and host infection remain poorly explored in these megadiverse and endangered ecosystems (Silveira et al., 2016).

In this study we assessed host range and distribution of the mistletoe P. robustus in an area of $C R$ in Serra do Cipó, South-eastern Brazil. We estimated $P$. robustus frequency of infection, as the fraction of infected trees of a given species from total infected trees sampled; infection prevalence, as the fraction of infected trees from all trees sampled for a given host species; and intensity of infection, as the number of mistletoes per infected tree for a given host species. We evaluated the spatial distribution of this mistletoe at the host tree and vegetation scales, and the relationship between host tree size and infection parameters (i.e. prevalence and intensity). In addition, we specifically addressed the following questions: (1) Is the frequency of parasitism by $P$. robustus directly related to the relative abundance of host tree species in the community? (2) How prevalence and intensity of infection vary among different host tree species?

\section{Methods}

\subsection{Area description}

We conducted this study at a private area in the vicinity of Serra do Cipó National Park $\left(43^{\circ} 35^{\prime} \mathrm{W}, 19^{\circ} 17^{\prime} \mathrm{S}\right)$, a mountain formation that is part of the Espinhaço Range in Eastern Brazil. The main vegetation at mountain tops is the $C R$, with plant communities establishing on quartzite-derived rocks, with shallow, acid, sandy and extremely nutrient-impoverished soils, mostly above $900 \mathrm{~m}$ asl (Silveira et al., 2016). The vegetation is characterized by a mosaic formed by patches of small tortuous trees growing on rocky outcrops and boulders, among a variety of shrubby species amidst a well-developed herbaceous stratum, and patches of natural grasslands, with herbs and shrubs sparsely distributed. The climate is markedly seasonal with rainy summers and dry winters. Mean monthly temperature ranges from $8^{\circ} \mathrm{C}$ in July to $29^{\circ} \mathrm{C}$ in February, and mean annual precipitation is nearly $1400 \mathrm{~mm}$ (Madeira and Fernandes, 1999). Altitudes at the study site vary from nearly $1100-1300 \mathrm{~m}$ asl.

\subsection{Field procedures}

We systematically set seven 1 -ha $(100 \times 100 \mathrm{~m})$ plots located $100 \mathrm{~m}$ apart from each other along a 2-km trail including campo rupestre vegetation. Between June and December 2007, we randomly selected a plot at monthly intervals in which we extensively surveyed mistletoes on potential host plants, including shrubs, herbs, vines and trees. To estimate $P$. robustus infection prevalence and intensity of infection we considered only those tree species that were previously observed as the most common host at the study site. Then, for each of these host tree species taller than $0.5 \mathrm{~m}$, we recorded species identity, presence and number of $P$. robustus individuals, tree height $\mathrm{TH}$; the distance from trunk base to canopy top) using a measuring pole and trunk base diameter (TBD; measured at soil height using a diameter tape, Forestry Suppliers (C)). All trees within the plot were carefully inspected for detection of mistletoes, and inspection time varied from few seconds to up to $30 \mathrm{~min}$ according to host tree size and number of mistletoes. We climbed those larger trees for a closer inspection and we also utilized and $8 \times 24$ binoculars to search for mistletoes in the canopy of trees from the ground. We could count mistletoes accurately since most trees are usually small $(>5 \mathrm{~m})$ and because mistletoes are conspicuous (Fig. 1), do not present epicortical secondary roots and the haustorium connects to hosts by single stem (Fig. 1ab). We considered only live mistletoes individuals, including established seedlings larger than $5 \mathrm{~cm}$ in height.

\subsection{Statistical analyzes}

To evaluate the effectiveness of the sampling effort in determining $P$. robustus host range at the study site, we constructed a rarefaction curve based on infected individuals found inside sampling plots. We compared the observed number of host species to an estimated value, obtained by first order Jackknife estimator after 1000 randomized samplings with replacement, utilizing the program EstimateS 9.0 (Colwell, 2013). To determine the degree of mistletoe aggregation at landscape scale we utilized the variance/mean ratio for abundances found on plots following Krebs (1989). To determine the degree of mistletoe aggregation at host tree scale we fitted observed distribution to expected negative binomial distribution for each host species, using chi-square goodness-of-fit test according to Krebs (1989). This statistical approach is commonly utilized to describe aggregation of plant parasites within hosts (Aukema and Martinez del Rio, 2002b; Medel et al., 2004). We utilized G-test to evaluate whether the frequency of parasitism on distinct host tree species corresponded to their relative abundance at the study site. Because host size had a strong effect on prevalence, to evaluate the correspondence among parasitism frequency and relative abundance, we excluded all trees with $\mathrm{TH}$ inferior to the shortest tree infected for each host species. We found significant positive correlations among TH and TBD for all tree species (log transformed data; $V$. thyrsoidea: $R^{2}=0.65, P<0.0001, \mathrm{n}=671 ; Q$. cordata: $R^{2}=0.63$, $P<0.0001, \mathrm{n}=87 ;$. laniflora, $R^{2}=0.47, P<0.0001, \mathrm{n}=188 ;$ $M$. ferruginata: $R^{2}=0.62, P<0.0001, \mathrm{n}=162$ ). Therefore, to conduct the analyzes we used only $\mathrm{TH}$. To determine differences in intensity of infection among host species we utilized the non-parametric Kruskal-Wallis test. The relationship among infection intensity and $\mathrm{TH}$ was evaluated separately for each host species using non-parametric Spearman rank correlations. We used logistic regressions to evaluate the effect of plant size (TH) on probability of infection for each host species. We used multiple regression models to assess the combined effects of tree density and mean tree height on (1) mistletoe density on plots and (2) mistletoe prevalence on plots, in two separate models. We performed statistical analyzes after checking the assumptions of normality and variance homogeneity in STATISTICA 7.0 (StatSoft, 2004). The significance level adopted for all analyzes was $\alpha=0.05$ and all analyzes were performed according to Zar (2010).

\section{3-Results}

\subsection{Host range}

We observed $P$. robustus parasitizing eight species within five families inside sampling plots. Four tree species were the most 

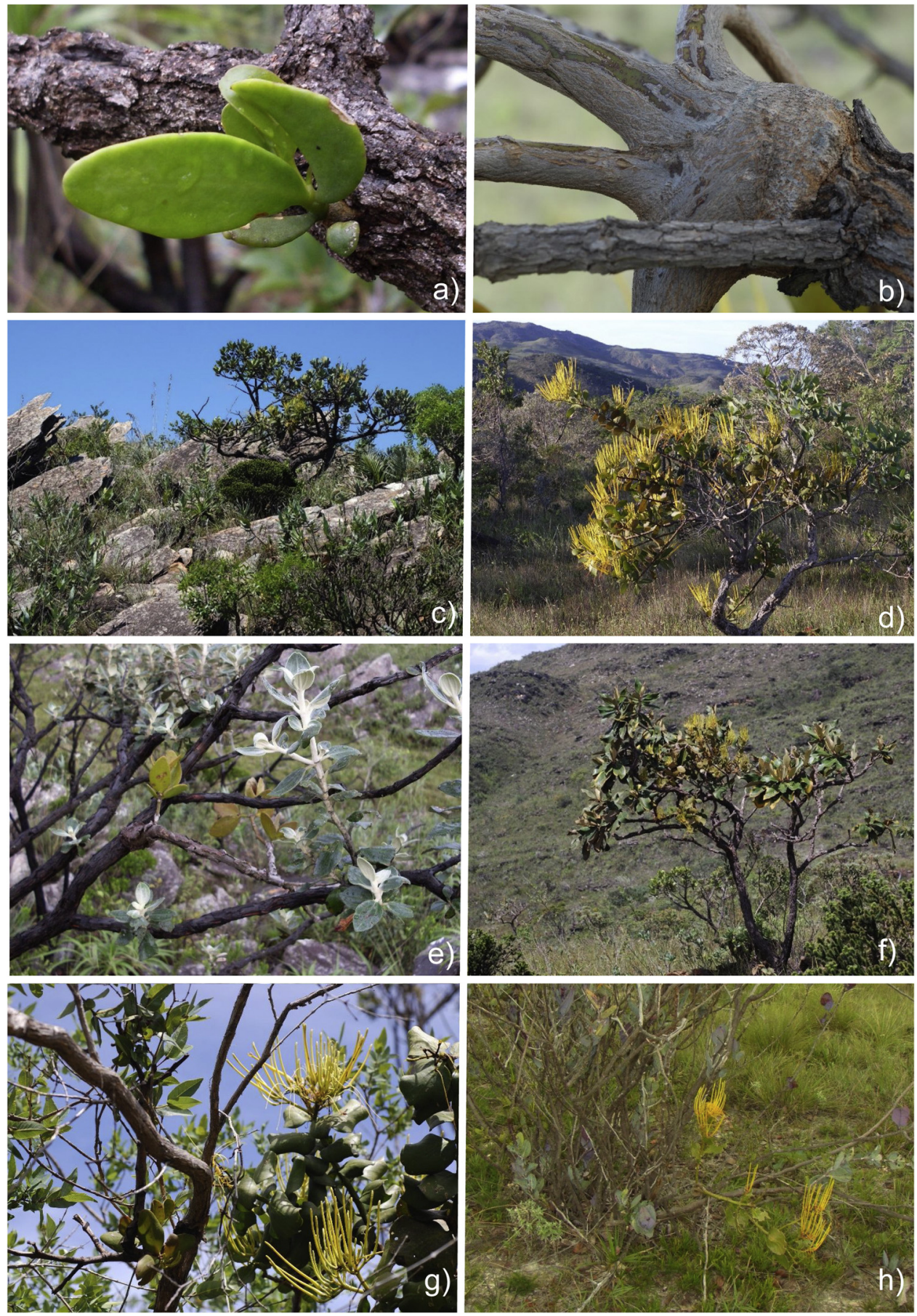

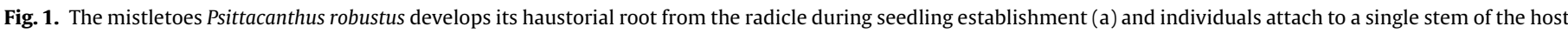

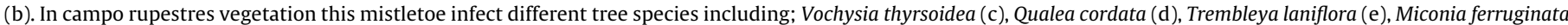
(f), Campomanesia adamantium (g) and Coccoloba cereifera (h).

common hosts among 255 infected plants recorded: Vochysia thyrsoidea Pohl (infection frequency 56\%, Fig. 1c), Qualea cordata Spreng. (19\%, Fig. 1d)(Vochysiaceae), Trembleya laniflora Cong. (15\%, Fig. 1e) and Miconia ferruginata DC. (4\%, Fig. 1f) (Melastomataceae). In addition, we found $P$. robustus parasitizing sporadically other four shrub species, including six individuals of Vochysia elliptica Mart., three individuals of Campomanesia adamantium Blume (Myrtaceae, Fig. 1g), one individual of Diplusodon hirsutus DC (Lythraceae) and two individuals of Coccoloba cereifera Schawcke (Polygonaceae,
Fig. 1h). We also recorded other two host species on nearby areas outside sampling plots, the tree Qualea dichotoma (Mart.)Warm and the shrub Miconia albicans Steud., indicating that $P$. robustus host range in campo rupestre at Serra do Cipó reach at least 10 species. The rarefaction curve for $P$. robustus reached an asymptote of eight host species after nearly 200 infected individuals sampled (Fig. 2). Host species richness estimated was $9.1 \pm 1.0$ (Mean \pm SD), indicating that our sampling effort was effective in assessing $P$. robustus host range in campo rupestre vegetation at Serra do Cipó. 


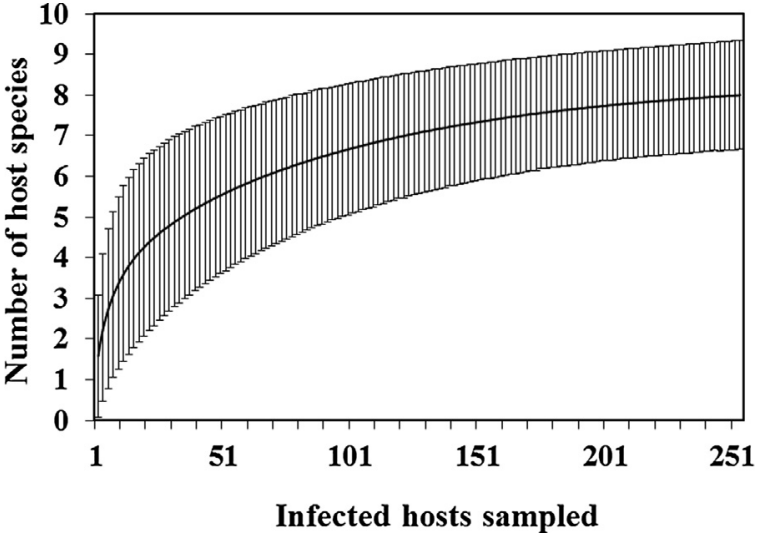

Fig. 2. Individual-based rarefaction curve for host species richness of Psittacanthus robustus in campo rupestre vegetation, Serra do Cipó, South-eastern Brazil.

\subsection{Mistletoe distribution}

Density of $P$. robustus varied from two to 342 individuals (mean $\pm \mathrm{SD}, 120 \pm 113$ plants $\mathrm{ha}^{-1}$ ) and was not related to tree density or mean tree height on plots $\left(F_{2,4}=0.75, R^{2}=0.27, P=0.52\right)$. Variance/mean ratio $(=106)$ was significantly larger than one $(P<0.001)$, indicating that mistletoe distribution is highly aggregated at campo rupestre vegetation. Distribution within hosts was also highly aggregated, with most trees uninfected, most infected plants parasitized by few mistletoes and just a small fraction of host trees heavily parasitized (Fig. 3a). The low $k$ values in the negative binomial distribution indicated highly clumped distribution of $P$. robustus within trees. In effect, distribution of mistletoes on hosts did not differ from negative binomial distribution for $V$. thyrsoidea $\left(\mu=0.57, k=0.150, \chi^{2}=9.1, d f=9, P=0.422\right)$, $Q$. cordata $\left(\mu=3.74, k=0.312, \chi^{2}=5.9, d f=10, P=0.816\right)$, and $T$. laniflora $\left(\mu=0.61, k=0.138, \chi^{2}=9.3, d f=5, P=0.093\right)$. Data for $M$. ferruginata also indicated clumped distribution ( $\mu=0.11, k=0.081$ ), but was insufficient for fitting negative binomial distribution.

\subsection{Prevalence and intensity of infection}

From 1,108 potential host trees examined 243 were parasitized (22\%). Prevalence ranged from $2 \%$ to $41 \%$ among plots and was not related to tree density or mean tree height on plots $\left(F_{2,4}=0.47, R^{2}=0.19, P=0.65\right)$. Prevalence varied among the host tree species (Table 1 ) and infection frequency differed significantly from expected based on their relative abundances $(G=45.0, d f=3$, $P<0.001)$. Qualea cordata occurred in lower densities $(12.4 \pm 14.5$ plants ha ${ }^{-1}$ ), comprising only $7.7 \%$ of trees sampled, but nearly $20 \%$ of all trees parasitized. Conversely, $M$. ferruginata $(23.1 \pm 30.2$ plants ha ${ }^{-1}$ ) represented nearly $16 \%$ of trees sampled, but only $4.5 \%$ of infected hosts. Vochysia thyrsoidea (mean \pm SD, $95.8 \pm 26.8$ plants ha $\mathrm{a}^{-1}$ ) was the most common host at the study site, representing nearly $61 \%$ of trees sampled and $59 \%$ of infected hosts, and T. laniflora ( $26.8 \pm 12.1$ plants ha $\left.^{-1}\right)$ represented nearly $17 \%$ of hosts and $16 \%$ of infected trees. After excluding plant in TH classes not infected by $P$. robustus, the pattern remained the same $(G=28.7$, $d f=3, P<0.001$, Fig. 3b).

Tree height varied significantly among host species, with $Q$. cordata and $M$. ferruginata being significantly taller than $V$. thyrsoidea and $T$. laniflora $\left(H_{3,1108}=45.4, P<0.001\right.$, Table 1$)$. Logistic regression models indicated that probabilities of infection by $P$. robustus raised significantly with increasing $\mathrm{TH}$ in all host species (Fig. 3c), V. thyrsoidea $\left(\chi^{2}=75.8, P<0.0001, Y=\exp (-3.17\right.$ $\left.+(0.84)^{*} X\right) /\left(1+\exp \left(-3.17+(0.84)^{*} X\right)\right), Q$. cordata $\left(\chi^{2}=15.5\right.$, $\mathrm{P}<0.001, Y=\exp \left(-2.48+(1.16)^{*} X\right) /\left(1+\exp \left(-2.48+(1.16)^{*} X\right)\right), T$.
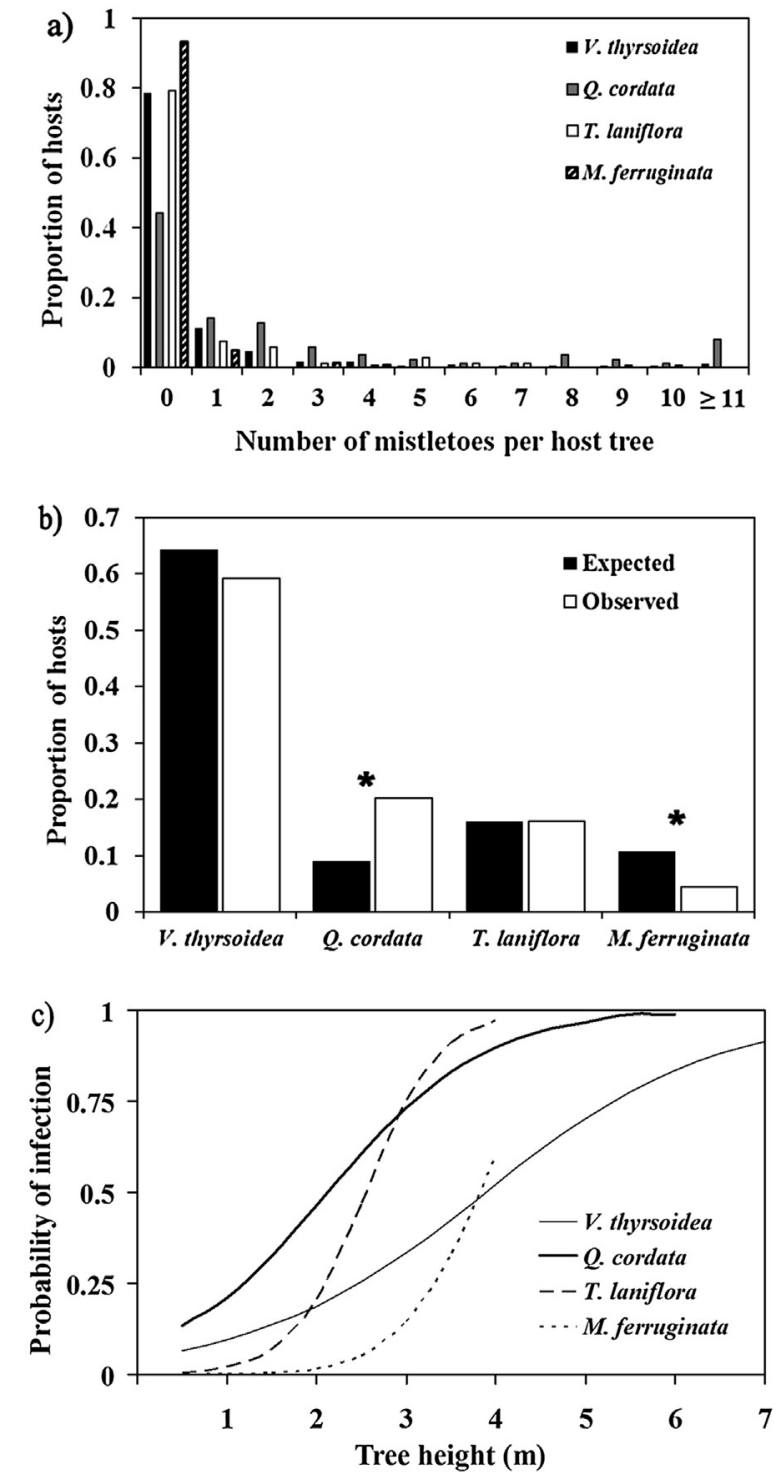

Fig. 3. (a) Aggregated distribution of Psittacanthus robustus infections per host tree in campo rupestre site, South-eastern Brazil. (b) Among species variation in observed infection frequencies, as the species proportion from 243 infected host trees sampled and expected infection frequencies, according to species proportional abundance from 947 trees sampled including infected and uninfected plants. Species proportional abundance were calculated after excluding 161 trees with TH inferior to the shortest tree infected for each host species. Asterisks denote significant statistical deviation from expected values $(\mathrm{P}<0.01)$. (c) Positive relationship between host tree height and probability of infection by $P$. robustus on four host species.

laniflora $\left(\chi^{2}=45.8, \mathrm{P}<0.0001, Y=\exp \left(-6.28+(2.46)^{*} X\right) /(1+\exp \right.$ $\left.\left(-6.28+(2.46)^{*} X\right)\right)$, for $M$. ferruginata $\left(\chi^{2}=16.7, P<0.001, Y=\exp \right.$ $\left(-8.46+(2.21)^{*} X\right) /\left(1+\exp \left(-8.46+(2.21)^{*} X\right)\right)$.

Intensity of infection was higher for $Q$. cordata than for $V$. thyrsoidea and $M$. ferruginata, with T. laniflora not differing from the other species $\left(H_{3,243}=20.7, P=0.0001\right.$, Table 1$)$. Despite the clear effects of $\mathrm{TH}$ on infection prevalence, infection intensity was positively correlated to $\mathrm{TH}$ only for $V$. thyrsoidea $\left(r_{\mathrm{s}}=0.27, P<0.001\right.$, $\mathrm{n}=144)$, but not for $Q$. cordata $\left(r_{\mathrm{s}}=0.26, P=0.067, \mathrm{n}=49\right)$, . laniflora $\left(r_{\mathrm{s}}=0.30, P=0.059, \mathrm{n}=39\right)$ and $M$. ferruginata $\left(r_{\mathrm{s}}=-0.33, P=0.31\right.$, $\mathrm{n}=11)$.

\section{Discussion}

Here, we showed novel host species for P. robustus, which infects disproportionally taller trees within Vochysiacea family. This 
Table 1

Parameters of host infection by the mistletoe Psittacanthus robustus (Loranthaceae) in campo rupestre vegetation, Serra do Cipó, South-eastern Brazil. Intensity of infection represents the number of mistletoes per tree, considering variance only for those parasitized trees. Prevalence is the fraction of infected trees from all trees sampled for a given host species.

\begin{tabular}{|c|c|c|c|c|}
\hline & \multicolumn{4}{|l|}{ Host species } \\
\hline & V. thyrsoidea & Q. cordata & T. laniflora & M. ferruginata \\
\hline Number of trees & 671 & 87 & 188 & 162 \\
\hline Prevalence & 0.21 & 0.57 & 0.20 & 0.07 \\
\hline \multicolumn{5}{|c|}{ Intensity of infection } \\
\hline Range & $1-30$ & $1-58$ & $1-10$ & $1-4$ \\
\hline Median & $1^{\mathrm{a}}$ & $3^{b}$ & $2^{a}$ & $1^{\mathrm{a}}$ \\
\hline Mean & 2.7 & 6.6 & 3.2 & 1.6 \\
\hline$\pm \mathrm{SD}$ & 3.9 & 9.8 & 2.7 & 1.1 \\
\hline $\mathrm{n}$ & 144 & 49 & 39 & 11 \\
\hline \multicolumn{5}{|l|}{ Tree height (m) } \\
\hline Range & $0.53-7.0$ & $0.70-5.9$ & $0.50-3.7$ & $0.55-3.8$ \\
\hline Median & $1.8^{\mathrm{a}}$ & $2.3^{b}$ & $1.7^{\mathrm{c}}$ & $2.2^{\mathrm{b}}$ \\
\hline Mean & 2.0 & 2.4 & 1.8 & 2.2 \\
\hline$\pm \mathrm{SD}$ & 1.5 & 1.4 & 1.4 & 1.4 \\
\hline $\mathrm{n}$ & 671 & 87 & 188 & 162 \\
\hline
\end{tabular}

mistletoe presented an aggregated distribution within hosts and at some campo rupestre vegetation patches. The highly aggregated distribution within host trees and habitat patches corroborates patterns reported for other mistletoes elsewhere (Aukema, 2004; Fadini et al., 2009; Hist et al., 2011), also reported for P. robustus in other sites in Brazil (Monteiro et al., 1992; Teodoro et al., 2010). The main biological mechanism explaining these patterns of distribution is related to the behavior of seed dispersal agents. First, foraging bird dispersers can perch more often on hosts with fruiting mistletoes, generating clumped seed deposition on already parasitized plants (Aukema and Martinez del Rio, 2002b; Medel et al., 2004). Second, foraging dispersers can track abundance of fruiting plants on habitat patches, leading to an increased infection in areas with higher mistletoe prevalence (Martínez del Rio et al., 1996; Garcia et al., 2009). We agree with Teodoro et al. (2010), who suggested that foraging decisions made by avian dispersers are likely to create a positive feedback process leading to a clumped pattern of seed distribution and, consequently, promoting spatial aggregation of $P$. robustus at host and vegetation scales. Nevertheless, the role of avian seed dispersers shaping patterns of distribution of $P$. robustus need proper investigations in the future.

We found $P$. robustus parasitizing $Q$. cordata more frequently than expected by its abundance, suggesting that host tree infection is not random. Differences in mistletoe prevalence among hosts can be related to several processes. Certain hosts can be more compatible than others, resulting in differences in establishment rates among host species (López de Buen and Ornelas, 2002; Fadini, 2011). Bird dispersers could perch preferentially on some tree species, leading to increased seed deposition on larger host trees (Aukema and Martinez del Rio, 2002b; Roxburgh and Nicolson, 2005; Fadini et al., 2009). Monteiro et al. (1992) also suggested that the preference of $P$. robustus for Qualea grandiflora was related to the behavior of the swallow tanager (Tersina viridis), which usually perch and deposit seeds on the canopy of taller trees. Thus, higher prevalence on $Q$. cordata could be related to population structure of this species that was the tallest species among host trees, although other process require proper evaluation.

Considering tree height as a proxy of plant age, our data indicates that probability of infection rise fast for older hosts. Indeed, positive age prevalence is a common pattern of infection among mistletoes (Overton, 1994; Aukema and Martinez del Rio, 2002a; Roxburgh and Nicolson, 2007), including P. robustus (Teodoro et al., 2010). This pattern could be related to longer periods of exposition to mistletoe vectors by older plants (Overton, 1994), but also to variation in establishment success of mistletoes growing on hosts at different life stages (Roxburgh and Nicolson, 2007). This positive relationship between size and prevalence could also be explained by the behavior of seed dispersers together with host characteristics. Some bird dispersers preferentially perch on taller hosts with larger canopies, resulting in higher chances of seed deposition in those older individuals (Aukema and Martinez del Rio, 2002a; Roxburgh and Nicolson, 2007; Fadini et al., 2009). Moreover, this pattern could also be related to low fire tolerance in some mistletoe species (Fadini and Lima, 2012). In effect, fire can increase mortality rates of $P$. robustus, and those plants infecting taller host trees could be less susceptible to negative effect of superficial fires as pointed out by Teodoro et al. (2013).

We updated the host pool of $P$. robustus adding species in distinct families totaling 17 host species in five families, indicating this species as less specialized than previously thought (Monteiro et al., 1992; Teodoro et al., 2010). Although sporadic, we also found $P$. robustus parasitizing species from three angiosperm families without reports, remarkable the infection on $C$. serifera, an endemic and threatened species found exclusively at Serra do Cipó (Ribeiro and Fernandes, 2000). The degree of host specificity is highly variable among Psittacanthus species studied so far. For instance, $P$. cordatus seem to be the most generalist species known, infecting 32 host species from at least 17 families in a single site in Brazilian Pantanal (Genini et al., 2012). Psittacanthus schiedeanus also present low degree of specialization, infecting 19 host species in 11 families at cloud forests in Mexico (López de Buen and Ornelas, 1999). Conversely, P. biternatus and P. eucalyptifolius infect seven and two host species, respectively, at an Amazonian Savanna site in northern Brazil (Fadini and Lima, 2012). However, up to now most studies failed to evaluate the effect of sampling effort on the host species richness found on single localities. Our study highlights the need of using rarefaction procedure to determine more accurately the host range of mistletoes and other parasitic plants.

Current information indicates that identity and the number of host species also vary significantly across $P$. robustus geographic range, with higher specialization occurring in some populations. This mistletoe can infect a single host tree in some sites (Teodoro et al., 2010), whereas in other localities it can infect up to eight host species in two families (Monteiro et al., 1992), or even ten species in five families as we recorded in CR. This data corroborate the idea that host range of Psittacanthus species might vary among localities. For instance, Caíres et al. (2009) reported P. plagiophyllus parasitizing 15 species in ten families in Pantanal woodlands in central Brazil, whereas Fadini and Lima (2012) found the same mistletoe species exclusively on cashew trees in an Amazonian Savanna.

Nearly $85 \%$ of $P$. robustus individuals sampled were found on Vochysiaceae species that represented nearly $78 \%$ of infected hosts, thus confirming high frequency of species within this family as hosts of P. robustus (Monteiro et al., 1992; Teodoro et al., 2010). In effect, $V$. thyrsoidea seem to be a dominant tree species in rocky outcrop patches. According to Norton and Carpenter (1998), the evolution of specialization between mistletoes and their hosts can be favored when compatible host species are highly abundant and predictably distributed. In concordance with this hypothesis, Vochysiaceae species, an exclusive Neotropical family, usually occur in high densities in Brazilian Cerrado physiognomies where $P$. robustus is commonly found. For instance, Silva et al. (2008) sampled over 135,000 trees in the largest assessment of Cerrado strictu sensu physiognomy and found 668 species in 78 families, with Vochysiaceae, especially Qualea species, being by far the most abundant family with nearly $20 \%$ of the trees sampled.

We found $P$. robustus parasitizing species in families Vochysiaceae and Melastomateceae, but also Myrtaceae and Lythraceae, which are all included in the Order Myrtales (APG, 2009). Thus, host 
specificity in $P$. robustus could be related to anatomical adaptations that allow haustorial attachment to bicollateral vascular bundles and vestured pits in the vessel elements, wood features shared by species within this clade (Conti et al., 1996). In addition, is important to note that aluminum accumulation is especially common in the Myrtales, especially in Melastomataceae (Jansen et al., 2002), a clade highly diversified and dominant at the $C R$ (Silveira et al., 2016). This fact suggests that aluminum accumulation by the hosts could be also involved in the evolution of host tree specialization by $P$. robustus. This mistletoe requires high concentrations of this element, which would be available through tapping the xylem of the Al-accumulating host species within Myrtales (Scalon et al., 2013).

In short, $P$. robustus was mostly associated to species within Myrtales clade, especially trees in Vochysiaceae family. When compared to other species in the genus, this mistletoe presented an intermediate degree of host specificity that varies among populations of this widely distributed species. Within the population studied, we found that $Q$. cordata was the tallest and preferred host tree. Psittacanthus robustus population presented an aggregated distribution within few taller host trees in some $C R$ patches. By unveiling patterns of host infection and mistletoe distribution, we paved the way for future studies addressing the processes involving plant-plant, bird-plant and fire-plant interactions that might shape infection dynamics of this widespread mistletoe species in campo rupestre ecosystems.

\section{Acknowledgments}

We thank F. Camarota, G. Sossai and V. Canoa for helping with field work. Dr. G.W. Fernandes for permission to conduct this study in his property. G.Q. Romero, F.A.O. Silveira, L.P.C. Morellato and two anonymous reviewers for their constructive comments and suggestions on different versions of the manuscript. T.J.G. was supported by doctoral fellowship from CAPES. This project was suported by a reseach grant from São Paulo Research Foundation (FAPESP, grant\#2007/59444-4). Some materials utilized on this research were donated by Ideawild. M.A. Pizo acknowledges a research productivity scholarship from CNPq.

\section{References}

Angiosperm Phylogeny Group, 2009. An update of the Angiosperm Phylogeny Group classification for the orders and families of flowering plants: APG III. Bot. J. Linn. Soc. 161, 105-121.

Arruda, R., Carvalho, L.N., Del-claro, K., 2006. Host specificity of a Brazilian mistletoe, Struthanthus aff. polyanthus (Loranthaceae), in cerrado tropical savanna. Flora 201, 127-134.

Arruda, R., Fadini, R.F., Carvalho, L.N., Del-Claro, K., Mourão, F.A., Jacobi, C.M., Teodoro, G.S., van den Berg, E., Caires, C.S., Dettke, G.A., 2012. Ecology of neotropical mistletoes: an important canopy-dwelling component of Brazilian ecosystems. Acta Bot. Bras. 26, 264-274.

Aukema, J.E., Martinez del Rio, C., 2002a. Where does a fruit-eating bird deposit mistletoe seeds? Seed deposition patterns and an experiment. Ecology 83, 3489-3496.

Aukema, J.E., Martinez del Rio, C., 2002b. Variation in mistletoe seed deposition: effects of intra- and interspecific host characteristics. Ecography 25, 139-144.

Aukema, J.E., 2004. Distribution and dispersal of desert mistletoe is scale-dependent, hierarchically nested. Ecography 27, 137-144.

Botto-Mahan, C., Medel, R., Ginocchio, R., Montenegro, G., 2000. Factors affecting the circular distribution of the leafless mistletoe Tristerix aphyllus (Loranthaceae) on the cactus Echinopsis chilensis. Rev. Chil. Hist. Nat. 73. $525-531$

Caíres, C.S., Uchôa-Fernandes, M.A., Nicácio, J., Strikis, P.C., 2009. Frugivoria de larvas de Neosilba McAlpine (Diptera, lonchaeidae) sobre Psittacanthus plagiophyllus Eichler (Santalales, Loranthaceae) no sudoeste de Mato Grosso do Sul, Brasil. Rev. Bras. Entomol. 53, 272-277.

Calder, M., Bernardt, P. (Eds.), 1983. The Biology of Mistletoes. Academic Press, Sidney.

Colwell, R.K., 2013. EstimateS: Statistical estimation of species richness and shared species from samples. Version 9. User's Guide and Application [http://viceroy. eeb.uconn.edu/EstimateS] (Assessed 18 October 2016).
Conti, E., Litt, A., Sytsma, K.J., 1996. Circumscription of Myrtalens and their relationships to other rosids: evidence from rbcL sequence data. Am. J. Bot. 82, 221-233.

Ehleringer, J.R., Schulze, E.D., Ziegler, H., Lange, O.L., Farquhar, G.D., Cowar, I.R., 1985. Xilem-tapping mistletoes: water or nutrients parasites? Science 227, 1479-1481.

Fadini, R.F., Lima, A.P., 2012. Fire and host abundance as determinants of the distribution of three congener and sympatric mistletoes in an Amazonian savanna. Biotropica 44, 27-34.

Fadini, R.F., Gonçalves, D.C.M., Reis, R.P.F., 2009. Consistency in seed deposition and the distribution of mistletoe among its hosts trees in an Amazonian Savanna. Aust. J. Bot. 57, 640-646.

Fadini, R.F., 2011. Non-overlap of hosts used by three congeneric and sympatric loranthaceous mistletoe species in an Amazonian savanna: host generalization to extreme specialization. Acta Bot. Bras. 25, 337-345.

Garcia, D., Rodriguez-Cabal, M., Amico, G., 2009. Seed dispersal by a frugivorous marsupial shapes the spatial scale of a mistletoe population. J. Ecol. 97, 217-229.

Genini, J., Côrtes, M.C., Guimarães Jr., P.R., Galetti, M., 2012. Mistletoes play different roles in a modular host-parasite network. Biotropica 44, 171-178.

Guerra, T.J., Camarota, F., Castro, F.S., Schwertner, C.F., Grazia, J., 2011. Trophobiosis between ants and Eurystethus microlobatus Ruckes 1966 (Hemiptera: Heteroptera: Pentatomidae) a cryptic, gregarious and subsocial stinkbug. J. Nat. Hist. 45, 1101-1117.

Guerra, T.J., Galetto, L., Silva, W.R., 2014. Nectar secretion dynamic links pollinator behavior to consequences for plant reproductive success in the ornithophilous mistletoe Psittacanthus robustus. Plant Biol. 16, 956-966.

Hist, L., Shaanker, R.U., Ghazoul, J., 2011. The spatial distribution of mistletoe in a southern Indian tropical forest at multiple scales. Biotropica 43, 50-57.

Hoffmann, A.J., Fuentes, E.R., Cortes, I., Liberona, F., Costa, V., 1986. Tristerix tetrandrus (Loranthaceae) and its host plants in the Chilean matorral: patterns and mechanisms. Oecologia 69, 202-206.

Jansen, S., Watanabe, T., Smets, E., 2002. Aluminium accumulation in leaves of 127 species in Melastomataceae, with comments on the order Myrtales. Ann. Bot. $90,53-64$

Krebs, C.J., 1989. Ecological Methodology. Harper and Row, New York.

López de Buen, L., Ornelas, J.F., 1999. Frugivorous birds, host selection and the mistletoe Psittacanthus schiedeanus, in Central Veracruz, Mexico. J. Trop. Ecol. $15,329-340$.

López de Buen, L., Ornelas, J.F., 2002. Host compatibility of the cloud forest mistletoe Psittacanthus schiedeanus in Central Veracruz, Mexico. Am. J. Bot. 89, 95-102.

Madeira, J.A., Fernandes, G.W., 1999. Reproductive phenology of sympatric taxa of Chamaecrista (Leguminosae) in Serra do Cipó, Brazil. J. Trop. Ecol. 15, 463-479.

Martínez del Rio, C., Silva, A., Medel, R., Hourdequin, M., 1996. Seed dispersers as disease vectors: birds transmission of mistletoes seeds to plant hosts. Ecology 77, 912-921.

Medel, R., Vergara, E., Silva, A., Kalin-Arroyo, M., 2004. Effects of vector behavior and host resistance on mistletoe aggregation. Ecology 85, 120-126.

Medel, R., 2000. Assessment of parasite-mediated selection in a host-parasite system in plants. Ecology 8, 1554-1564.

Monteiro, R.F., Martins, R.P., Yamamoto, K., 1992. Host specificity and seed dispersal of Psittacanthus robustus (Loranthaceae) in south-east Brazil. J. Trop. Ecol. 8, 307-314.

Mourão, F.A., Carmo, F.F., Ratton, P., Jacobi, C.M., 2006. Hospedeiras da hemiparasita Struthanthus flexicaulis (Mart.) Mart. (Loranthaceae) em campos rupestres ferruginosos do Quadrilátero Ferrífero. Minas Gerais. Lundiana 7. $103-109$.

Norton, D.A., Carpenter, M.A., 1998. Mistletoes as parasites: host specificity and speciation. Trends Ecol. Evol. 13, 101-105

Overton, J.M., 1994. Dispersal and infection in mistletoe metapopulations. J. Ecol. $82,711-723$.

Ribeiro, K.T., Fernandes, G.W., 2000. Patterns of abundance of narrow endemic species in a tropical and infertile montane habitat. Plant Ecol. 147, 205-218.

Rizzini, C.T., 1980. Loranthaceae of the Central Brasil. Arq. do Jardim Botânico do Rio de Janeiro 24, 19-50.

Roxburgh, L., Nicolson, S.W., 2005. Patterns of host use in two African mistletoes: the importance of mistletoe: host compatibility and avian disperser behavior. Funct. Ecol. 19, 865-873.

Roxburgh, L., Nicolson, S.W., 2007. Differential dispersal and survival of an African mistletoe: does host size matter? Plant Ecol. 195, 21-31.

Sargent, S., 1995. Seed fate in a tropical mistletoe: the importance of host twig size. Funct. Ecol. 9, 197-204.

Scalon, M.C., Haridasan, M., Franco, A.C., 2013. A comparative study of aluminium and nutrient concentrations in mistletoes on aluminium-accumulating and non-accumulating hosts. Plant Biol. 15, 851-857

Silva, C.P.C., Oliveira-Filho, A.T., van den BERG, E., Scolforo, J.R., Mello, J.M., Oliveira, A.D., 2008. Composição florística dos fragmentos inventariados. In: Scolforo, J.R., Mello, J.M., Oliveira, A.D. (Eds.), Inventário Florestal de Minas Gerais: Cerrado-Florística, Estrutura, Diversidade, Similaridade, Distribuição Diamétrica e de Altura, Volumetria, Tendências de Crescimento e Áreas Aptas para Manejo Florestal. Editora UFLA, Lavras, pp. 135-168.

Silveira, F.A.O., Negreiros, D., Barbosa, N.P.U., Buisson, E., Carmo, F.F., Carstensen, D.W., Conceição, A.A., Cornelissen, T.G., Echternacht, L., Fernandes, G.W., Garcia, Q.S., Guerra, T.J., Jacobi, C.M., Lemos-Filho, J.P., Le Stradic, S., Morellato, L.P.C., Neves, F.S., Oliveira, R.S., Schaefer, C.E., Viana, P.L., Lambers, H., 2016. 
Ecology and evolution of plant diversity in the endangered campo rupestre: a neglected conservation priority. Plant Soil 403, 129-152.

StatSoft(2004) STATISTICA (data analysis software system). Version 7. Tulsa,

(http://www.statsoft.com).

Teodoro, G.S., van den Berg, E., Santos, M.C.N., Coelho, F.F., 2010. How does a Psittacanthus robustus Mart. Population structure relate to a Vochysia thyrsoidea Pohl. host population? Flora 205, 797-801.

Teodoro, G.S., van den Berg, E., Arruda, R., 2013. Metapopulation dynamics of the mistletoe and its host in Savanna areas with different fire occurrence. PLoS One 8 (6), e65836, http://dx.doi.org/10.1371/journal.pone.0065836.
Watson, D.M., Rawsthorne, J., 2013. Mistletoe specialist frugivores: latterday 'Johnny Appleseed's or self-serving market gardeners? Oecologia 172, 925-932.

Yan, Z., 1993. Resistence to haustorial development of two mistletoes, Amyema preissii (Miq.) Tieghem and Lysiana exocarpi (Behr.) Tiegghem ssp. exocarpi. Int. J. Plant Sci. 154, 386-394.

Zar, J.H., 2010. Biostatistical Analysis, fifth ed. Prentice Hall, New Jersey. 